Vladimir Nedić ${ }^{1}$

The School of Applied Engineering Studies, Kragujevac

Dušan Cvetanović ${ }^{2}$

University of Niš, Faculty of Economics

Jovica Subotić

Secondary School of Economics, Kragujevac
SCIENTIFIC REVIEW ARTICLE doi:10.5937/ekonomika1701041N

Received: December, 01, 2016 Accepted: January, 25, 2017

\title{
REVERSING THE LOSS OF NATURAL RESOURCES AND SUPPORT TO THEIR REVITALIZATION IN THE WESTERN BALKANS
}

\begin{abstract}
Using data from the World DataBank for the period 1990-2015, relating to Ensure environmental sustainability, and Target A: Integrate the principles of sustainable development into country policies and programmes and reverse the loss of environmental resources within it, the paper presents comparative analysis of indicator values for the five countries of the Western Balkans (Albania, Bosnia and Herzegovina, Macedonia, Serbia, and Montenegro) and the EU28 average. The results show that the Western Balkan countries significantly lag behind the countries of the European Union in all five monitored indicators in the context of stopping the loss of natural resources and their revitalization.
\end{abstract}

Key words: sustainable development, millennium goals, natural resources

JEL classification: Q20, Q40, Q50

\section{ЗАУСТАВЉАЊЕ ГУБИТАКА ПРИРОДНИХ РЕСУРСА И ПОДСТЦАҢЕ ЊИХОВЕ РЕВИТАЛИЗАЦИЈЕ У ЗЕМЉАМА ЗАПАДНОГ БАЛКАНА}

\begin{abstract}
Апстракт
Користећи податке из базе података Светске банке за период 1990-2015., који се односе на праћење Обезбеђење еколошке одрживости, у оквиру тога Таргет А: Интегрисање приничипа одржсивог развоја у националне политике, заустављањегубитака природних ресурса и подстицање юихове ревитализације; у раду је презентована компаративна анализа вредности индикатора за пет земала Западног Балкана (Албанија, БИХ, Македонија, Србија и Црна Гора) и просека ЕУ28. Резултати истражсивања су показали да земље Западног Балкана изражено заостају по свих пет посматраних индикатора у оквиру
\end{abstract}

\footnotetext{
${ }^{1}$ vnedic@kg.ac.rs

2dusan.cvetanovic@ymail.com
} 
заустављања губитака природних ресурса и њихове ревитализаџије у односу на земье Европске уније.

Кључне речи: одржсии развој, миленијумски ииьеви, природни ресурси

\section{Introduction}

Sustainable development can be broadly defined as development that meets the needs of the present without compromising the ability of future generations (Elliott, 2012; Jovanović, Radukić \& Petrović-Ranđelović, 2011; Daly, H2006). Sustainable development is detected as the most urgent global problem since 1972, when it was placed in the United Nations Environmental Programme (see Petsonk, 1989), and for nearly four decades ago remain important areas of research of many disciplines (sociology, economics, ecology, technology, biology, geography, law and political science, as well as many others) and areas of national government policies as well as a number of international initiatives and projects.

Understanding sustainable development gradually expands by interconnecting sociology, economy and ecology into a kind of "magic triangle" of development (Figure. 1) (Filipovic \& Despotovic, 2014; Despotovic et al., 2015).

Figure 1: Three layers of sustainable development

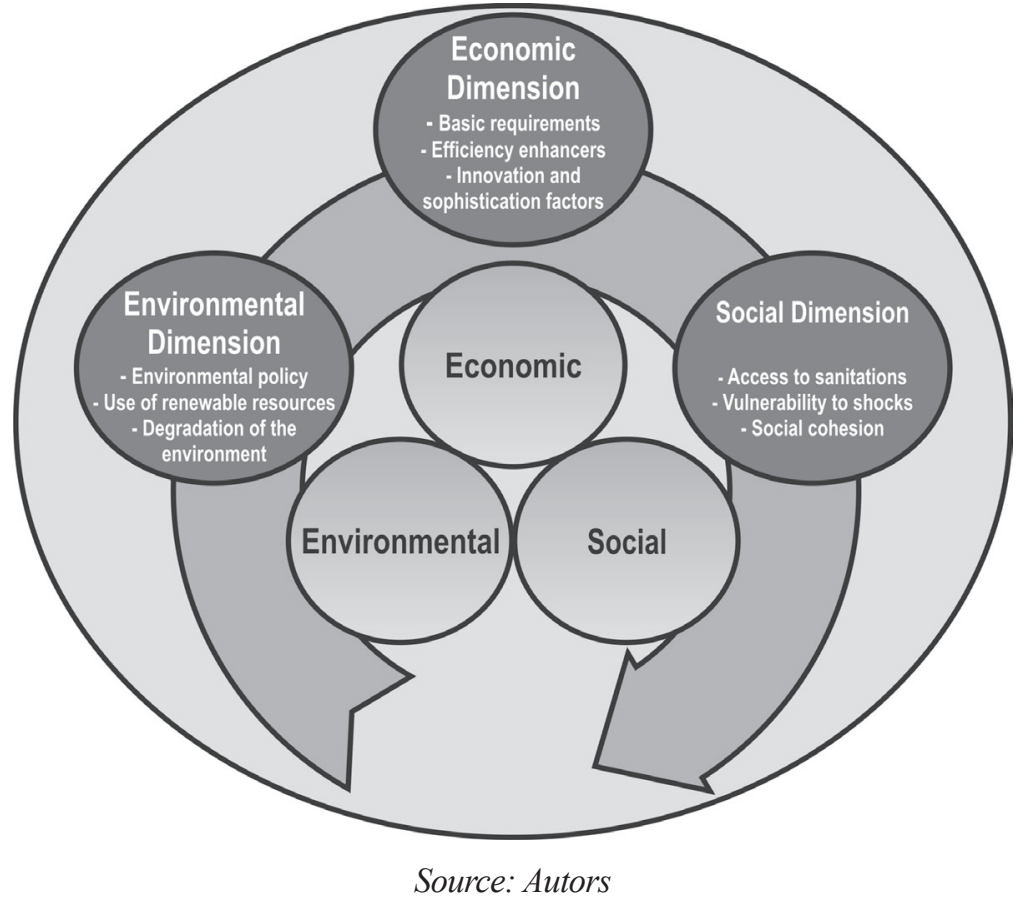

As stated in Pokrajac (2013), "this triangle for every civilized man should be a minimum not only an obligation, but a historic opportunity and space to prove himself as a humanist and a true globalists, to whom is truly important the entire world, not only his own, 
local part. Therefore, if we want to look to the future we must stand firmly on that tripod. If it fails just one leg, the picture of the future will be dangerously defective, distorted or incomplete, if possible at all."

Although the phenomenon of sustainability is considered by some authors in different ways, they have common or similar fundamental human and ethical principles: environmental security, social justice, human solidarity and compassion, tolerance, dignity and freedom of human beings, the balance of individual and social interests, ethnical, cultural and religious pluralism, free development of human creative potential. It is about the maturing of collective consciousness about the necessity of social change and transformation of that consciousness into the mass movement for the formation of new more righteous and more humane society (Mesarić, 2006).

The quality of the paradigm of sustainable development comes not only from the fact that it combines the most important economic, social and environmental criteria, but also from the circumstances that the concept creates a particular "methodological synergy". This confirms a) anthropocentric approach, which puts in the foreground people and their responsibility for sustainable development; b) long-term, understood as multitime synthesis c) spatial coverage, ranging from local to global (Pokrajac, 2002, 145).

The concept of sustainability is widely accepted nowadays. The reasons for this lie in possible answers to the question why economic activity must be sustainable (Kuik \& Verbruggen, 2012; Griggs, et al., 2013).

In the first place, there are strong moral reasons why modern generations leave a legacy of much less development opportunities to their descendants, compared to what they have now. This means that the planet Earth, with its resources, must not be degraded by humans. This reasoning is based on Rawls's theory of justice, which highlights the fundamental principle of moral justice, contained in the equal right of every individual to the widest fundamental freedoms, which do not contradict the freedom of others (Rawls, 1971; Pogge $\&$ Kosch, 2007). Thus, the right of present generation to use resources and the environment must not compromise the same rights of generations to come.

The second group of reasons regarding sustainable development is of environmental nature (Krstic, 2014; Cvetanovic et al., 2014). Specifically, if the nature is a value in itself, i.e. if the preservation of biodiversity and stocks of natural resources is justified by the view that man is only a part of nature, then man has no right to irretrievably change it (CavenderBares, et al.,2013). Then not every form of economic activity that affects the diversity of wildlife and a wealth of resources can be acceptable. In fact, this group of reasons, too, can be reduced to moral reasons, noting that here the focus is not on attitude of the present towards future generations, but the attitude towards other living beings, i.e. towards nature as a whole (Karpiak \& Baril, 2008).

The third possible reason to justify the concept of sustainability can be the attitude that disregard for the concept of sustainability leads to inefficient economic development (Ambec, et al., 2013).

A special place in the operationalization of sustainability belongs to metrics defined at the Millennium Summit, held in New York in 2000 (Sachs \& McArthur, 2005). The importance of the Millennium Declaration (Assembly, 2000) is reflected in the definition of global norms that should be the basis of international relations in the 21 st century. The shortest possible, these are the norms that have been translated into the following eight goals: 1. Eradicate extreme poverty and hunger; 2 . Achieve universal primary education; 3 . Promote 
gender equality and empower women; 4. Reduce child mortality; 5. Improve maternal health; 6. Combat HIV/AIDS, malaria, and other diseases; 7. Ensure environmental sustainability; i

8. Develop a global partnership for development (See Figure 2).

Figure 2: Millennium Development Goals

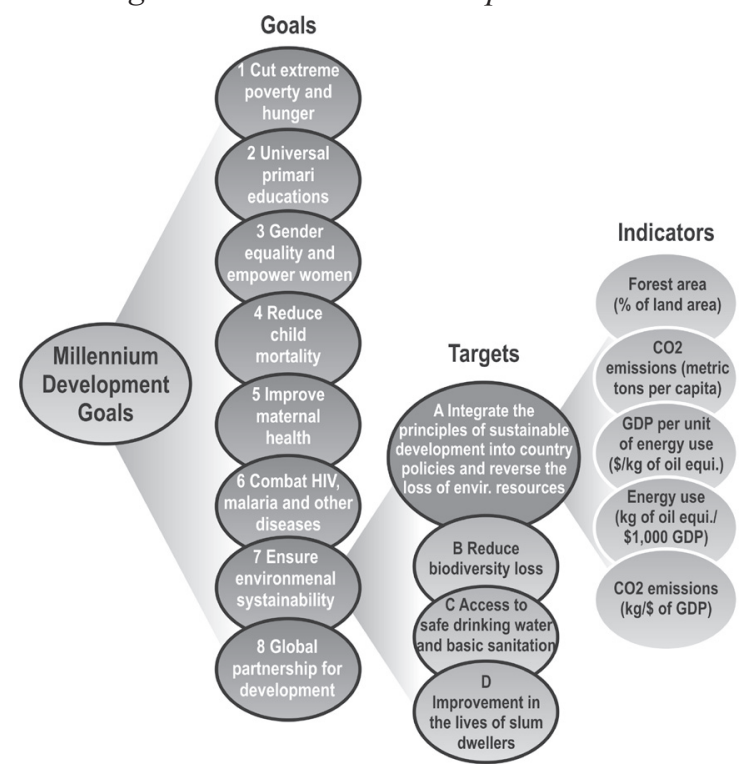

Source: Autors according Millennium Development Goals(n.d)

In this paper, the focus is on Goal 7: Ensure environmental sustainability. The realization of this goal is monitored by five groups of indicators (A: Integrate the principles of sustainable development into country policies and programmes and reverse the loss of environmental resources; B: Reduce biodiversity loss; C: Access to safe drinking water and basic sanatation and $\mathrm{D}$ : Improvenment in the lives of slum dwellers). We monitor the values of indicators within 7A (CO2 emissions (kg per PPP \$ of GDP); CO2 emissions (metric tons per capita); Energy use (kg of oil equivalent per \$1,000 GDP (constant 2011 PPP); GDP per unit of energy use (constant 2011 PPP \$ per kg of oil equivalent; and Forest area ( $\%$ of land area). The text that follows presents a comparative view of their values individually for the five countries of the Western Balkans (Albania, Bosnia and Herzegovina, Macedonia, Serbia, and Montenegro) and the EU28 average.

\section{Integration of the principles of sustainable development into country policies and programmes and reversing the loss of environmental resources of the Western Balkans and the EU in the period 1990-2013}

One of the main problems in the world in recent decades is global warming. Proposals for its solution are very different. One of the most frequently mentioned solutions is to reduce CO2 emission (Manne \& Richels, 1991). CO2 emission is quantified in different ways (kg per PPP \$ of GDP; metric tons per capita). 
Figure 3 shows the trend of CO2 emissions kg per PPP \$ of GDP in five countries of the Western Balkans and the European Union in the period 1990-2013.

Figure 3: CO2 emissions (kg per PPP \$ of GDP)

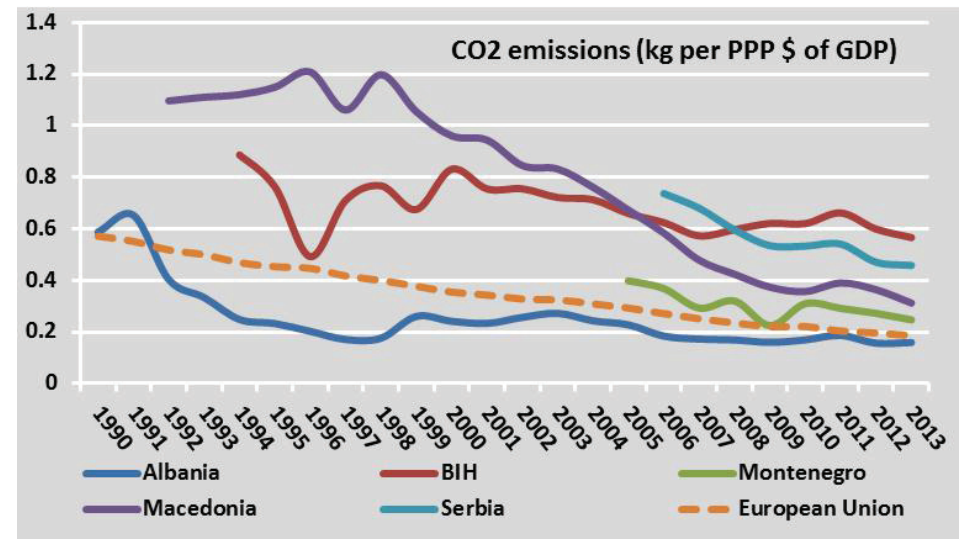

Source: Millennium Development Goals| World DataBank. (n.d)

In the reporting period, since 1990, the intensity of CO2 emissions was much higher in the surveyed countries of the Western Balkans than the EU average. It was not until 2003 that the Western Balkan countries started showing declining trend, but a large gap in relation to the EU average is still evident. In addition, throughout the reporting period, EU countries were characterized by steady downward trend of CO2 emissions (kg per PPP \$ of GDP), while in all the countries of the Western Balkans there was a tendency of pronounced oscillations of $\mathrm{CO} 2$ emissions by years in the observed time interval.

Figure 4 shows the trend of $\mathrm{CO} 2$ emissions (metric tons per capita) in five countries of the Western Balkans and the European Union in the period 1990-2013.

Figure 4: CO2 emissions (metric tons per capita)

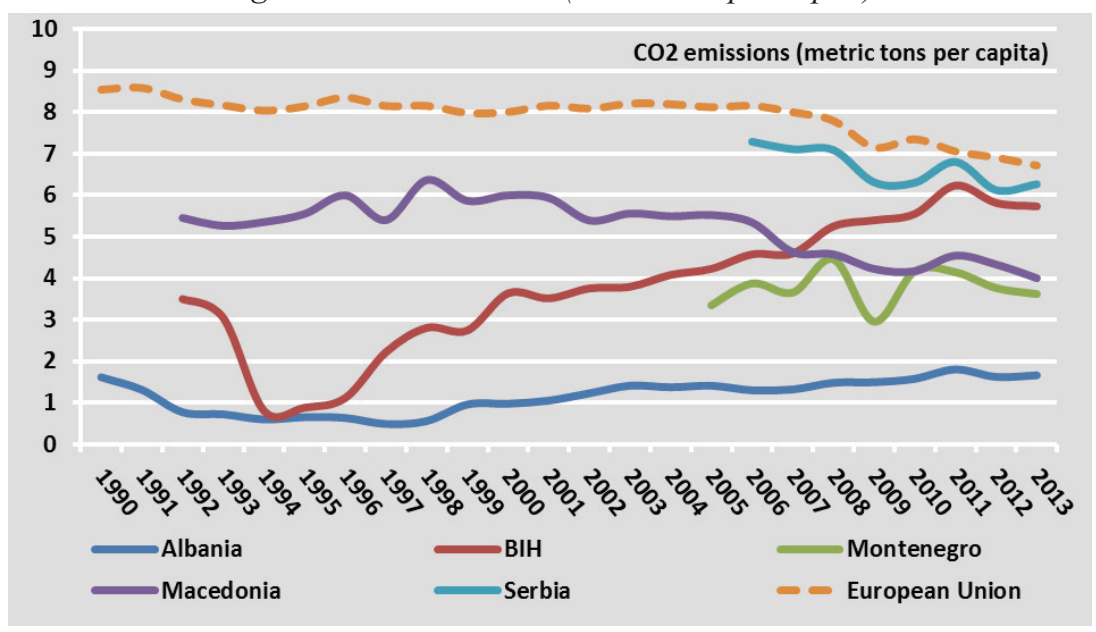

Source: Millennium Development Goals $\mid$ World DataBank. (n.d) 
Diagram in Figure 4 shows that the EU countries, observed by $\mathrm{CO} 2$ emissions (metric tons per capita), are still bigger polluters than all other observed Western Balkan countries, although showing a slight downward trend. In addition, still high levels of pollution in the EU may be partly justified by high efficiency, i.e. lowest CO2 emissions (kg per PPP \$ of GDP) (compared to the observed Western Balkan countries) (Figure 3).

On the other hand, countries of the Western Balkans do not indicate a trend towards improvement, based on the parameter of $\mathrm{CO} 2$ emissions (metric tons per capita), except for Serbia, which is, after the EU, the biggest polluter in this parameter among the countries observed. The best ranked country is Albania, although it increased this emission from 0.5 in 1997 to 1.7 tons per capita in 2013.

Over 80 percent of the world's energy comes from fossil fuel resources. It is anticipated that the global demand will continue to grow by 2030, which imposes the imperative of efficient use of energy. One of the indicators of the efficiency of energy use is certainly an indicator Energy use ( $\mathrm{kg}$ of oil equivalent) per \$1,000 of GDP in constant prices (Figure 5).

Figure 5: Energy use (kg of oil equivalent) per \$1,000 GDP (constant 2011 PPP)

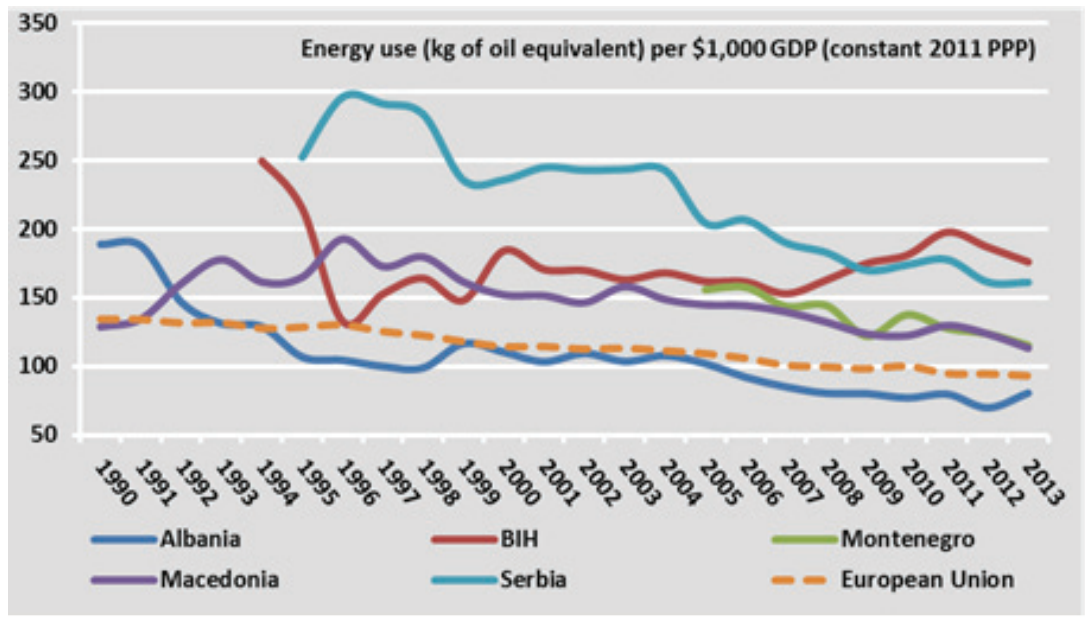

Source: Millennium Development Goals $\mid$ World DataBank. (n.d)

Parameter of primary energy consumption per unit of GDP is, as expected, almost the most favorable in the EU (as the average value of the members), with the most stable trend of improvement. The only country in the Western Balkans with approximate and better results is Albania (Ralchev, 2012).

Serbia shows the worst efficient use of primary energy, but trend of improvement is still evident. In 2013, primary energy consumption per unit of gross domestic product in the Republic of Serbia amounted to 0.16 tons/1000 \$ of GDP (constant 2011 PPP), according to the World Bank data (Millennium Development Goals | World DataBank. (n.d.)), which shows a significant decline relative to the value of 0.3 tons/1000 \$ of GDP in 1996. This still represents a very high value, although countries like Turkmenistan (0.37), Ukraine (0.31), Uzbekistan (0.28), South Africa (0.21), Russian Federation (0.2), and Kazakhstan (0.2) had higher values of this parameter in 2013. On the other hand, in developed countries (OECD), the value of this parameter in 2014 was about 0.11 , while in the EU it was only 0.09 . This 
means that Serbia consumed 2 times more energy per unit of gross domestic product than the EU, suggesting a considerable need for energy rationalization.

Figure 6: GDP per unit of energy use (constant 2011 PPP \$ per $\mathrm{kg}$ of oil equivalent)

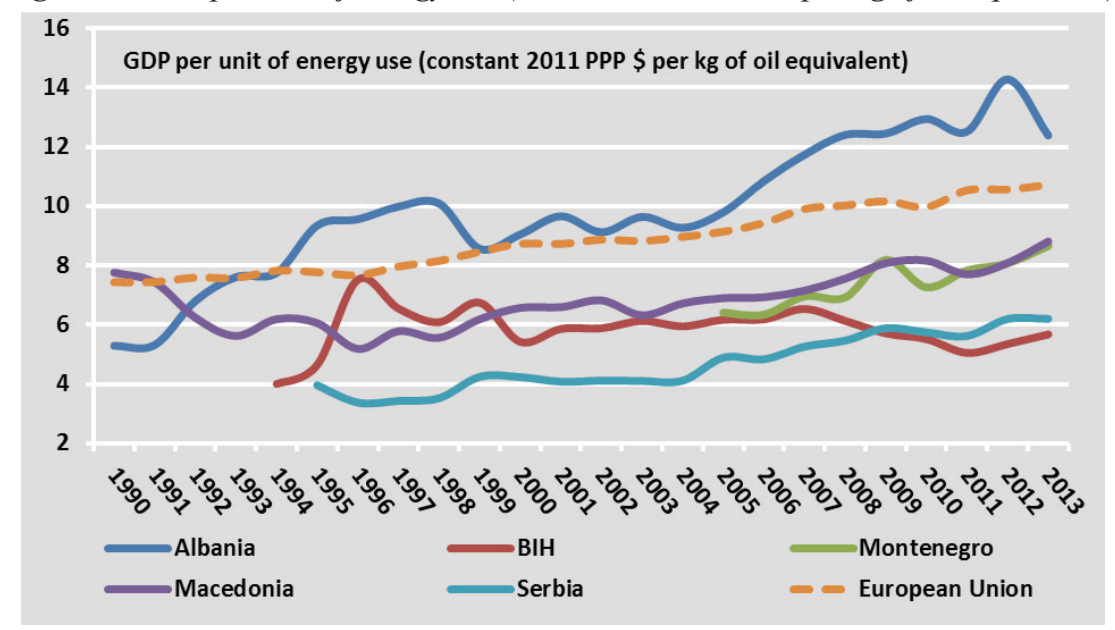

Source: Millennium Development Goals $\mid$ World DataBank. (n.d)

It can be said that energy efficiency in the Republic of Serbia is one of the lowest (Figure 6): With extremely low energy efficiency in all sectors of energy consumption (industry, transport, agriculture, public and utility services, and households), high use of electricity for heating purposes is also characteristic. Increasing energy efficiency is necessary because of the growing problems in the global energy sector, which are directly reflected on the domestic energy situation: rising prices of energy generating products (large fluctuations in prices of energy generating products on the world market since the crisis period of 2008) and the need to secure long-term energy sources and reduce dependence on imports, as well as to protect and preserve the environment. In the end, it is also one of the conditions that must be achieved in the process of harmonization and accession of Serbia to the European Union.

Deforestation causes significant loss of biodiversity, while values associated with biodiversity are significant externalities, which are rarely reflected on market prices (Figure 7). 
Figure 7: Forest area (\% of land area)

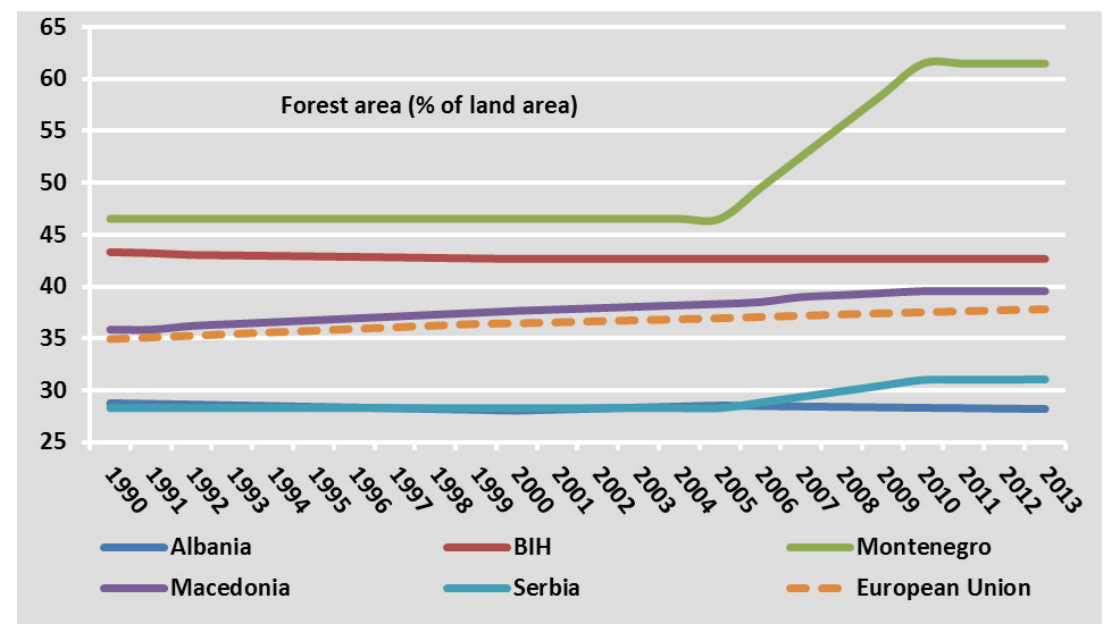

Source: Millennium Development Goals| World DataBank. (n.d)

Forests, as the most valuable part of the ecosystem, capable of significantly improving general living conditions, occupy a very important place in the global concept of protection and improvement of the environment, which is why they require special treatment through an appropriate system of protection, use, and management of all functions of forests in the context of sustainable development. Forested areas cover $31.1 \%$ of the total area of the Republic of Serbia, which shows a positive trend compared to $28.3 \%$ in 1990 and a move from the last to the second to last place in the group of observed countries (the increase was achieved in the period from 2005 to 2010). Relatively speaking, Montenegro had the best results based on this parameter, while the EU average in 2013 was about $38 \%$.

\section{Conclusion}

A special place in the operationalization of the sustainability category belongs to metrics defined at the Millennium Summit, held in New York in 2000. The importance of the Millennium Declaration is reflected in the definition of global norms that should be the basis of international relations in the 21 st century.

Data observed implies that the Western Balkan countries significantly lag behind the EU average in all five indicators of reversing losses of natural resources and their revitalization (CO2 emissions (kg per PPP \$ of GDP); CO2 emissions (metric tons per capita); Energy use (kg of oil equivalent) per \$1,000 GDP (constant 2011 PPP); GDP per unit of energy use (constant 2011 PPP \$ per kg of oil equivalent; and Forest area (\% of land area). 


\section{References}

Ambec, S., Cohen, M. A., Elgie, S., \& Lanoie, P. (2013). The Porter hypothesis at 20: can environmental regulation enhance innovation and competitiveness?. Review of Environmental Economics and Policy, 7(1), 2-22.

Assembly, U. G. (2000). United Nations millennium declaration. United Nations General Assembly.

Cavender-Bares, J., Heffernan, J., King, E., Polasky, S., Balvanera, P., \& Clark, W. C. (2013). Sustainability and biodiversity.

Cvetanovic, S., Despotovic, D., Zivkovic, LJ. and Nedic, V. 2014. Environmental Dimension of Sustainable Competitiveness of Serbia and Selected European Countries. Bulgarian Journal of Agricultural Science, Vol 20, No 4.

Daly, H. E. (2006). Sustainable development-definitions, principles, policies. In The future of sustainability (pp. 39-53). Springer Netherlands.

Despotovic, D., Cvetanovic, S., Nedic, V., \& Despotovic, M. (2015). Economic, social and environmental dimension of sustainable competitiveness of European countries. Journal of Environmental Planning and Management, 1-23.

Elliott, J. (2012). An introduction to sustainable development. Routledge.

Filipovic, M., \& Despotovic, D. (2014). Analysis of Sustainable Competitiveness of European Countries in 2013. Ekonomika, 60(4), 77-91.

Griggs, D., Stafford-Smith, M., Gaffney, O., Rockström, J., Öhman, M. C., Shyamsundar, P., ... \& Noble, I. (2013). Policy: Sustainable development goals for people and planet. Nature, 495(7441), 305-307

Jovanović, S., Radukić, S., \& Petrović-Ranđelović, M. (2011). Teorijski i institucionalni okvir održivog razvoja. Ekonomski fakultet Univerziteta u Nišu, Niš.

Karpiak, C. P., \& Baril, G. L. (2008). Moral reasoning and concern for the environment. Journal of Environmental Psychology, 28(3), 203-208.

Krstic, B. (2014). Importance Of Implementing The Green Economy Concept And Its Impact On Financial Performance Of An Enterprise. Ekonomika, 60(1), 60-68

Kuik, O. J., \& Verbruggen, H. (Eds.). (2012). In search of indicators of sustainable development (Vol. 1). Springer Science \& Business Media

Manne, A. S., \& Richels, R. G. (1991). Global CO2 emission reductions: the impacts of rising energy costs. In Global Climate Change (pp. 211-239). Springer Netherlands.

Mesarić, M. 2006. Obrisi novog, socijalno pravednog, ekonomski učinkovitog i ekološki održivog modela, Ekonomski pregled, 57 (12) 939-969

Millennium Development Goals| World DataBank. (n.d.). Retrieved November 10, 2016, fromhttp://databank.worldbank.org/data/reports.aspx?source=millenniumdevelopment-goals

Petsonk, C. A. 1989. Role of the United Nations Environment Programme (UNEP) in the Development of International Environmental. Law. Am. UJ Int'l L. \& Pol'y, 5,351 . 
Pogge, T. W. M., \& Kosch, M. (2007). John Rawls: his life and theory of justice. Oxford University Press on Demand.

Pokrajac, S. 2002. Tehnologija, tranzicija i globalizacija, Savez naučnih stvaralaca Srbije, Beograd.

Pokrajac, S. 2013. Održivi razvoj i ekološka ekonomija kao poslovne paradigme, Škola biznisa, Novi Sad: Visoka poslovna škola, str.

Ralchev, S. (2012). Energy in the western Balkans: a strategic overview. Institute for Regional and International Studies, Sofia.

Rawls, J. (1971). A Theory of Justice. Cambridge: Harvard Univesity Press.

Sachs, J. D., \& McArthur, J. W. (2005). The millennium project: a plan for meeting the millennium development goals. The Lancet, 365(9456), 347-353. 